\author{
Julija Vaitonytè \\ Vilnius University, Lithuania \\ Julija Korostenskienè \\ Vilnius University, Lithuania
}

\title{
FEMININE IMAGERY IN CONTEMPORARY AMERICAN POP SONGS: A CONTRASTIVE ANALYSIS
}

\begin{abstract}
Summary. For over a decade, metaphor analysis has been postulated as a powerful means of unveiling human experience encoded in various spheres of language use. Proposing a hypothesis that even within a single culture, the views of a particular social group may alter significantly within a relatively short period of time with pop songs being an immediate reflection of the change, the present study explores feminine imagery as constructed in American pop songs by leading female pop singers in two ten-year periods: from 1985 to 1995 and from 2005 to 2015. Set within the framework of Conceptual Metaphor Theory, the study employs the Metaphor Identification Procedure developed by Pragglejaz Group and P.A.N., a poetry analysis software, in order to identify and conduct qualitative analysis of conceptual metaphors that construe feminine imagery. The findings are drawn on the basis of 522 conceptual metaphors whose most common targets are love, life, and time. It is shown that, while in both periods the contemporary woman construes her image as a strong, persistent and self-dependent leader, the earlier period is characterized by more positive views on love while in latest times woman's relationships are characterized by a greater dynamism: the woman of today conceives life as both competitive and risky and yet is able to adapt seeking to take up a leading role in relationships. There is also evidence that most recently, woman has developed a more aggressive attitude toward love in particular and a more pragmatic attitude toward life in general.
\end{abstract}

Keywords: conceptual metaphor, feminine imagery, pop songs, metaphor identification procedure, target domain.

\section{Introduction}

Prior to the 1970s, the complex relationship between language and mind had been frowned upon. Until then the behaviourist approach to language was dominant: language was viewed as a series of learned behaviours, suggesting that language is a response to stimuli in the environment (Skinner, 1957). The emergence of Cognitive linguistics in the late 1970s, which brought about Conceptual Metaphor Theory, initially proposed by Lakoff and Johnson (1980) and more recently further advanced by Grady (2005), Gibbs (2011) and Steen (2011), led to a notion that language use is based on "vast cognitive and 
Julija VAITONYTE், Julija KOROSTENSKIENE்

cultural resources" evoked through "creative mappings, transfers, and elaborations" (Fauconnier, 2003, p. 1).

Cognitive linguistics rehabilitated metaphor, which had previously been relegated to literary tradition and assumed to be but a rhetoric device. Arguing that meaning is not to be viewed as passive; it is created in the course of discourse through "particular cultural models and cognitive resources" (Fauconnier, 2003, p. 2). Perceived as manifest in every written or spoken interaction, discourse then constitutes "a dynamic form of social practice which constructs the social world, individual selves and identity" (Jørgensen, Phillips, 2002, p. 129).

Within the domain of music, performers communicate ideas through their songs via two channels, sound and lyrics. Song lyrics is a text: any form of written material, in which a totality of ideas is expressed in a creative way. As noted by Machin, "music can be an authentic expression of the soul and also indicate certain individual dispositions" (2010, p. 26), which consequently suggests that, songs reflect the performer's world view or mind set (cf. Cameron, 2001). The term "world view" or "mind set" refers to "the possible reflection in language of an individual's perception of the surrounding world" since "every person may perceive and conceptualise all aspects of reality differently" (Dhooge, 2008, pp. 146-147).

Given the notion that one's language reflects one's perception of reality, an analysis of conceptual metaphors applying Conceptual Metaphor Theory to song lyrics can offer insights into one's "world view" or "mind set" and, taken more broadly, be suggestive of the values prevalent in the society at a given time. Due to their form, conceptual metaphors reveal the presence of certain constituents of the "world view", in other words, abstract concepts, such as life, time, emotions, mentality, etc. The present study applies Conceptual Metaphor Theory to contemporary American pop songs in order to analyse and compare metaphors from two periods so as to establish how the feminine world is constructed by female performers. It is hypothesized that in two different periods feminine views will be encoded through different metaphors, hence women are expected to "speak different languages", with the analysis 
ultimately perceived as containing the multilingual component. The aim is therefore twofold: to identify the metaphor set characteristic of both periods and to determine the domains in which feminine worldviews diverge.

\section{Theoretical background}

Prior to the pioneering work of Lakoff and Johnson (1980), metaphor in the Western tradition had been viewed as a literary device, a trope that draws on the comparison between two things or aspects. In their seminal work Metaphors We Live By, Lakoff and Johnson (1980) advanced a completely different notion: metaphor is a matter of thought and reasoning. Unlike the classical literary approach, Cognitive linguistics has given the metaphor a more immediate and spontaneous status. Metaphor is no longer viewed as a consciously constructed figure of speech; rather, it is thinking of one domain in terms of another. Lakoff and Johnson claim that "human thought processes are largely metaphorical" (1980, p. 6). They argue that metaphors are employed in structuring everyday human concepts, which is reflected in our daily language use, ultimately claiming that people both talk and think metaphorically. As Cserép puts it, "our language is saturated with metaphors, rooted in recurring bodily experience, and our language is metaphorical simply because our conceptual system is metaphorical" (2014, p. 262). What is then the cognitive definition of metaphor? Cognitive scientists view conceptual metaphor as a projection of two different semantic domains, which enables people to understand the abstract through the concrete. In Conceptual Metaphor Theory, metaphor is defined as understanding of one domain of experience in terms of a very different domain of experience: CONCEPTUAL DOMAIN $A$ IS CONCEPTUAL DOMAIN $B$. The two domains have specific names: the conceptual domain, from which metaphorical linguistic expressions are drawn, is the source domain (domain $B$ ); the conceptual domain, which is understood this way, is the target domain (domain $A$ ). With the source domain being concrete and the target domain abstract, conceptual metaphor is a mapping, in other words, a set of correspondences, transferred from a source domain to a target domain to describe how bodily experience 
Julija VAITONYTE், Julija KOROSTENSKIENE்

(concrete source domain) interacts with mental understanding of things (abstract domain) (Kövecses, 2010). In language, conceptual metaphor takes a form of the so-called metaphorical linguistic expressions which can be defined as words or other linguistic expressions that come from the language of the more concrete conceptual domain and are based on the original sense of a word to understand another conceptual domain or sphere (ibid.).

To illustrate, Lakoff and Johnson (1980) present an example of the ARGUMENT IS WAR conceptual metaphor and support it with several metaphorical linguistic expressions drawn from everyday language:

- He attacked every week point in my argument.

- His criticism were right in the target.

- I demolished his argument (Lakoff and Johnson, 1980, p. 4).

Conceptualising arguments in terms of war is an instance of conceptual metaphor since the second conceptual domain (war) is more concrete than the first one (arguments). Charteris-Black (2008) highlights the aspect of an interplay between mental understanding and bodily experience: metaphors serve the purpose of "mediating between minds as they understand the world, and bodies as they experience it" (p. 2). Consequently the "experientialist" component of the CMT is sometimes emphasised.

Conceptual metaphors are structured hierarchically relative to each other thereby reflecting their degree of conventionality, i.e., how well estabilished and how deeply rooted they are in the everyday usage of a linguistic community. For example, conventional conceptual metaphors, such as LIFE IS A JOURNEY, ARGUMENT IS WAR, TIME IS MONEY, IDEAS ARE FOOD are the most usual ways of thinking of an abstract domain (life, argument, time, ideas) (Kövecses, 2010, p. 34). The fact that a given metaphorical linguistic expression causes no difficulties in understanding it, presupposes that it expresses a conventional way to reason about life, reflected in people's literal language. 


\section{Methodology}

The study rests on the assumption that the feminine world is best manifested by women themselves. To examine the feminine "mind set" through the analysis of conceptual metaphors, 190 pop songs by best-selling American female solo performers, influential in contemporary music industry, have been selected from two ten-year periods: from 1985 to 1995 and from 2005 to 2015 (hereinafter referred to as Period 1990s and Period 2000s respectively), with 95 songs selected from each period. The songs were chosen by referring to the record chart for singles "Billboard Hot 100" on www.billboard.com. The sites used for the collection of lyrics were www.azlyrics.com as well as www.metrolyrics.com. Given the objectives of the study, duet songs were excluded from analysis, but feat songs, in which, in addition to a leading female performer, a male performer, usually a rapper, takes part, were collected, since they were still credited to a female singer. The analysis and classification of conceptual metaphors rests upon a combination of the quantitative, the qualitative and the comparative methods. The identification of conceptual metaphors was conducted applying the Metaphor Identification Procedure (MIP) devised by a group of scholars known as Pragglejaz Group (2007), whereby an examination of the meaning of the components of a given linguistic unit is conducted in order to 1) distinguish conceptual metaphors from nonmetaphorical, i.e., literal linguistics items; 2) group identified metaphors to their source domains.

As a supplementary tool, a computer software P.A.N. Poetry Analysed (P.A.N.) was used to ascertain that the method of entire selection of metaphors is conducted (http://pan.sourceforge.net). By means of grammatically parsing sentences, P.A.N. conducts the extraction of the recurrent concepts of the text submitted for analysis. Each song is manually and individually fed into the program so that a basis for song analysis is formed. P.A.N.'s analysis results provides detected elements (such as, love, peace, spirituality, youth, femininity, the natural, life, purity and so on), a list of conflicting themes (such as, the physical and spiritual, positivity and negativity, deceit and honesty, ignorance and awareness) and preliminary imagery of the text (for instance, "children are 
Julija VAITONYTĖ, Julija KOROSTENSKIENE்

our future"), all of which makes a good starting point for a comprehensive analysis of texts. As every computer program P.A.N., however, is limited in its ways of providing an in-depth analysis and was used as a supporting tool.

The data selection procedure was conducted in two stages. During the first stage, a total of 522 metaphors were identified and selected from the 190 pop songs examined from Period 1990s and Period 2000s. The identified metaphors were grouped according to their target domains. In the songs of both periods, the following target domains were identified: LOVE, LIFE, TIME, PEOPLE, SELF, POSSESSION AND CONTROL, CONDITION, MENTAL EVENTS, GOODNESS, HOPE, COMMUNICATION, and MORALITY.

During the second stage, the nature of metaphors was examined. It turned out that metaphors pertaining to the domains PEOPLE, SELF, POSSESSION AND CONTROL, CONDITION, MENTAL EVENTS, GOODNESS, HOPE, COMMUNICATION, and MORALITY are either instances of container metaphors, which are usually perceived as schemata for the construction of conceptual metaphors and should not be regarded as primary in analysis (Kövecses, 2010); or their frequency is too low to make generalisations possible. In addition, the preliminary analysis revealed that the greatest differences were identified in the domains of LOVE, LIFE, and TIME. Consequently these constituted the basis for further analysis with the total number of metaphors amounting to 331 : 223 metaphors of love, 87 metaphors of life and 21 metaphors of time. Table 1. below shows the distribution of the metaphors in both periods:

Table 1

\section{The distribution of metaphors in the three domains in two periods}

\begin{tabular}{|c|c|c|}
\hline Conceptual Metaphors of: & Period 1990s & Period 2000s \\
\hline love & 115 & 108 \\
\hline life & 57 & 30 \\
\hline time & 12 & 9 \\
\hline
\end{tabular}

To provide an interpretation of the selected metaphorical linguistic expressions structuring conceptual metaphors the qualitative and the comparative methods were employed. In addition, the conceptual analysis included a critical 
examination of concepts: the main question asked was how contemporary women create constructions of the world through discursive practise.

\section{Findings and discussion}

\section{Conceptual metaphors of love}

As can be seen, love is a primary focus in both periods. In fact, every pop song analysed touches upon the concept of love, which is structured metaphorically in a host of ways. Love is conceived through the following source domains: health and disease, animals, machines, games and sport, heat, forces, movement, and light.

Table 2. below presents all conceptual metaphors of love identified and their respective frequencies are provided. Naturally, a number of metaphors are directly related to the target domain of 'love': LOVED ONE IS A POSSESSION, LOVED ONE IS THE LIGHT, LUST IS FIRE, EMOTIONAL BONDING IS PHYSICAL BONDING, LUSTFUL PERSON IS AN ACTIVATED MACHINE and BEING IN A RELATIONSHIP IS WRITING A STORY. As the table suggests, the perception of love in the given periods does not vary substantially, but those conceptual metaphors that do differ are marked in bold.

Table 2

\section{Conceptual metaphors of love}

\begin{tabular}{|c|c|c|c|}
\hline Period 1990s & Quantity & Period 2000s & Quantity \\
\hline $\begin{array}{l}\text { LOVE IS A UNITY (OF TWO } \\
\text { COMPLEMENTARY PARTS) }\end{array}$ & 12 & LOVE IS MADNESS & 14 \\
\hline LOVE IS A DISEASE & 10 & LOVE IS WAR & 11 \\
\hline LOVE IS WAR & 9 & LOVE IS A DISEASE & 10 \\
\hline LOVE IS MADNESS & 9 & $\begin{array}{l}\text { LOVE IS A PHYSICAL } \\
\text { FORCE }\end{array}$ & 9 \\
\hline $\begin{array}{l}\text { LOVE IS BEING OFF THE } \\
\text { GROUND }\end{array}$ & 8 & $\begin{array}{c}\text { LOVE IS A UNITY OF } \\
\text { (TWO } \\
\text { COMPLEMENTARY } \\
\text { PARTS) }\end{array}$ & 6 \\
\hline LOVE IS AN ENTITY & 7 & LOVE IS AN ENTITY & 5 \\
\hline LOVE IS FALLING & 7 & LOVE IS FALLING & 5 \\
\hline LOVE IS FIRE & 7 & LOVE IS FIRE & 4 \\
\hline
\end{tabular}


Julija VAITONYTĖ, Julija KOROSTENSKIENE்

\begin{tabular}{|c|c|c|c|}
\hline Period 1990s & Quantity & Period 2000s & Quantity \\
\hline LOVE IS FISHING & 7 & $\begin{array}{c}\text { LOVE IS BEING OFF } \\
\text { THE GROUND }\end{array}$ & 4 \\
\hline LOVE IS A JOURNEY & 6 & LOVE IS MAGIC & 4 \\
\hline LOVE IS A STATE & 4 & LOVE IS FISHING & 3 \\
\hline LOVE IS BLINDING & 4 & LOVE IS A JOURNEY & 3 \\
\hline LOVE IS A LIVING ORGANISM & 3 & $\begin{array}{c}\text { LOVE IS A } \\
\text { GAMBLING GAME }\end{array}$ & 3 \\
\hline LOVE IS A PHYSICAL FORCE & 2 & LOVE IS BLINDING & 2 \\
\hline LOVE IS HEALTH & 2 & LOVE IS TORTURE & 2 \\
\hline LOVE IS MAGIC & 2 & LOVE IS A DRUG & 2 \\
\hline LOVE IS A VEHICLE & 2 & LOVE IS A NUTRIENT & 2 \\
\hline LOVE IS TORTURE & 2 & LOVE IS A VEHICLE & 2 \\
\hline LOVE IS A RESOURCE & 1 & $\begin{array}{c}\text { LOVE IS A MOVING } \\
\text { OBJECT }\end{array}$ & 1 \\
\hline LOVE IS A CONTAINER & 1 & $\begin{array}{c}\text { LOVE IS A } \\
\text { CONTAINER }\end{array}$ & 1 \\
\hline LOVE IS A GUARD & 1 & $\begin{array}{c}\text { LOVE IS A } \\
\text { SPORTING GAME } \\
\text { LOVE IS NATURE }\end{array}$ & 1 \\
\hline LOVE IS A NUTRIENT & 1 & $\begin{array}{c}\text { LOVED ONE IS A } \\
\text { POSSESSION }\end{array}$ & 2 \\
\hline LOVE IS A GUIDE & 1 & LUST IS FIRE & 2 \\
\hline LOVED ONE IS A POSSESSION & 6 & $\begin{array}{c}\text { LUSTFUL PERSON IS } \\
\text { AN ACTIVATED } \\
\text { MACHINE }\end{array}$ & 1 \\
\hline LUST IS FIRE & 3 & $\begin{array}{c}\text { BEING IN A } \\
\text { WELATIONSHIP IS }\end{array}$ & 1 \\
\hline WRITING A STORY \\
PHYSICAL BONDING
\end{tabular}

Due to space constraints, the conceptual metaphors with the highest number of occurrences will be discussed below. These are as follows: LOVE IS A UNITY OF (TWO COMPLEMENTARY PARTS), LOVE IS WAR, LOVE IS A DISEASE, LOVE IS MADNESS, LOVE IS A PHYSICAL FORCE and LOVE IS IS BEING OFF THE GROUND.

\section{LOVE IS A UNITY (OF TWO COMPLEMENTARY PARTS)}

The conceptual metaphor LOVE IS A UNITY (OF TWO COMPLEMENTARY PARTS) is present in pop songs of both periods, but is more common in the pop songs of Period 1990s. The metaphorical linguistic expressions by which this particular conceptual metaphor is realised are quite similar in both periods. Love is 
conceived as a unity of two people since it is implied that one is incomplete until his or her better half has not been found, as for instance:

- I found out what I've been missin'/Always on the run/I've been lookin' for someone (Whitney Houston, "You Give Good Love", 1985);

- I've had such fun around the world it's true/The one thing missing was you (Janet Jackson, "Runaway", 1995);

- You're part of my entity, here for infinity (Rihanna, "Umbrella", 2007);

- I finally found you/My missing puzzle piece/I'm complete (Katy Perry, "Teenage Dream", 2010).

In the same manner, losing a loved one implies losing a part of oneself:

- Losing my mind/From this hollow in my heart/Suddenly I'm so incomplete (Mariah Carey, "Love Takes Time", 1990);

- When you left I lost a part of me (Mariah Carey, "We Belong Together" 2005).

The conceptual metaphor LOVE IS A UNITY (OF TWO COMPLEMENTARY PARTS) can also be structured by a metonymical mapping between the source and the target domains: the whole thing for a part of the thing. Thus the heart stands for love in the following metaphorical linguistic expressions that construct this conceptual metaphor:

- The way you used to touch me felt so fine/We kept our hearts together down the line (Whitney Houston, "Didn't We Almost Have It All", 1987);

- Always thought of keeping/Your heart next to mine (Céline Dion, "Where Does My Heart Beat Now", 1991).

\section{LOVE IS WAR}

Pop songs of Period 1990s and Period 2000s are also structured by the conceptual metaphor LOVE IS WAR, with love often described through warrelated terms, for example: 
Julija VAITONYTE், Julija KOROSTENSKIENE்

- Tonight I'm gonna take you in dead or alive (Cher, "Just Like Jesse James", 1989);

- Boy, don't try to front (Britney Spears, "Womanizer", 2008);

- So I surrender to every word you whisper (Rihanna, "What's My Name?", 2010).

The LOVE IS WAR metaphor is a systematic conventional conceptual metaphor in which a series of mappings between the constituent elements of the source and the target domains appear. One of the correspondences is lovers are fighters, which suggests that in love, like in war, there are those who win and those who lose and have to surrender.

The conceptual metaphor LOVE IS WAR discloses how the image of the contemporary woman is construed in pop songs of both time periods. A number of metaphorical linguistic expressions reveal that woman is perceived as superior in power, exerting her influence over her lover, as evidenced in the first two examples above. In addition, the contemporary woman portrays herself as fierce in the relationships with her lover, which is a characteristic feature of the pop songs of Period 2000s, for instance:

- And when you enter, you ain't leavin', be my prisoner for the night (Rihanna, "Only Girl", 2010);

- It'll leave you breathless/Or with a nasty scar (Taylor Swift, "Blank Space", 2014).

When it is the woman who is hurt by her loved one, although 'defeated', she still remains strong and capable of recovering:

- Fought every gain/To taste the sweet/I face the pain/I rise and fall (Whitney Houston, "One Moment In Time", 1988);

- It takes more strength to cry, admit defeat (Madonna, "You'll See", 1995).

In this way, though the conceptual metaphor LOVE IS WAR, the feminine narrative portrays the contemporary woman as strong, self-reliant and most importantly, capable of inflicting pain and injury, the latter being a characteristic feature of the pop songs of Period 2000s. 


\section{LOVE IS A DISEASE}

Another frequent rendering of the target domain 'love' is through the source domain 'disease'. In both periods, love is regarded as a painful experience:

- My heart is full of pain (Whitney Houston, "Miracle", 1985);

- You can tell me when it's over/If the high was worth the pain (Taylor Swift, "Blank Space", 2014).

Another common feature is love conceptualised as an intoxication and infection. The correlation with an earlier idea is revealing: although woman portrays herself as inflicting pain, at the same time she also unconsciously craves to be hurt, which is best manifest in the pop songs of Period 2000s:

- I'm in love/I'm alive/Intoxicated (Mariah Carey, "Emotions", 1991);

- I thought love had to hurt to turn out right/But now he's here (Whitney Houston, "All The Man That I Need", 1991);

- You can be a sweet dream or a beautiful nightmare/Either way I, don't wanna wake up from you (Beyoncé, "Sweet Dreams", 2008);

- Infect me with your love and/Fill me with your poison (Katy Perry, "E.T.", 2010).

The above metaphorical linguistic expressions are revealing since they point to feminine endurance, which, together with the already pinpointed woman's attributes - strength and ferociousness - take an important place in the feminine imagery in both periods. The salience of the LOVE IS A DISEASE metaphor suggests that the contemporary woman, as portrayed in the pop songs of both time periods, finds the pain pleasant, and, in a sense, unconsciously craves for it.

\section{LOVE IS MADNESS}

The conceptual metaphor LOVE IS MADNESS is one of the fundamental metaphors by which love is structured in both in Period 1990s and Period 2000s. Notably, LOVE IS A DISEASE and LOVE IS MADNESS are two different 
Julija VAITONYTĖ, Julija KOROSTENSKIENE்

conceptual metaphors: whereas the former is concerned with structuring love in terms of the human body, the latter draws on human mind, for instance:

- I'm going crazy just to let you know/You'd be amazed how much I love you so baby (Donna Summer, "This Time I Know It's For Real", 1989);

- I'm going crazy over you (Rihanna, "S.O.S.", 2006).

In addition, the conceptual metaphor LOVE IS MADNESS structures love in terms of the act of losing control or balance:

- You know the way to make me lose control/When you're looking into my eyes (Whitney Houston, "Miracle", 1991);

- I'm driving out of control and getting ready to crash (Christina Aguilera, "Keeps Gettin' Better", 2008);

- You about to break me, I swear you got me losing my mind/ You got that something that keeps me so off balance (Rihanna, "What's My Name?", 2010).

\section{LOVE IS A PHYSICAL FORCE}

Being one of the strongest human emotions, love is frequently rendered through the domain of physical forces. This presupposes that love acts in the same manner as does physical force: it is extremely strong and barely controllable. While in pop songs of Period 2000s, love is primarily perceived in terms of a certain negative domain, for example, war, disease and madness, the metaphor LOVE IS A PHYSICAL FORCE, as illustrated below, suggests that in contemporary pop songs, love may also be perceived as an interaction between two opposing poles:

- I'll give you love, I'll hit you like a truck (Madonna, "Erotica", 1992);

- I make it sweet on the lips/I'll simply knock you out (Christina Aguilera, "Keeps Gettin' Better", 2005).

In the first example above, love is equalled to the hitting of a truck, while the second example is an instance of the oxymoron since it combines two completely different aspects, the sweetness and the act of knocking out. This fact correlates with some of the conclusions that have been already drawn about 
the concept of love in the pop songs of both time periods: though painful, love is an extremely strong emotion.

The analysis of the conceptual metaphor LOVE IS A PHYSICAL FORCE reveals that the most crucial aspect largely manifests in both time periods, but especially characteristic of the pop songs of Period 2000s is that woman consciously seeks roughness in her relationships with her lover and, in a way, perceives 'rough love' as the only possible kind of love that exists.

\section{LOVE IS BEING OFF THE GROUND}

LOVE IS BEING OFF THE GROUND is another metaphor commonly found in pop songs of Period 1990s and Period 2000s:

- You make me feel so/High (Mariah Carey, "Emotions", 1991);

- Boy, you're my temporary high (Beyoncé, "Sweet Dreams", 2008);

- This love will make you levitate (Katy Perry, "Dark Horse", 2013).

This conceptual metaphor can be regarded as having both positive and negative connotations, thereby reinforcing an earlier notion that the concept of love is conceived as neither positive, nor entirely negative, but rather as an opposing force. Interestingly, while LOVE IS BEING OFF THE GROUND is perceved as entirely positive in pop songs of Period 1990s, figures as rather negative in Period 2000s:

- Why am I standing on a cloud/Every time you're around (Madonna, "Angel", 1985);

- Gravity hurts/You made it so sweet/'Til I woke up on/On the concrete (Katy Perry, "Wide Awake", 2012).

To sum up this section, love is the most commonly addressed concept in pop songs of both Period 1990 s and Period 2000s. The target domain 'love' is primarily conceived through the source domains unity, war, disease, madness, physical force, and being off the ground. Period 2000s is also characterised by metaphors expressing more negative responses to love than those employed in Period 1990s. However, it would be misleading to claim that in pop songs of Period 2000s love is conceptualised only in negative terms; 
Julija VAITONYTĖ, Julija KOROSTENSKIENE்

rather, it is understood as a combination of two contradictory poles, e.g., I make it sweet on the lips/I'll simply knock you out.

\section{Conceptual metaphors of life}

The target domain life is viewed in terms of three source domains: journey, game and dramatic performance. Conceptual metaphors of life with the source domain journey constitute the majority of metaphors in pop songs of both time periods. Metaphors of life with the source domain game are more common in pop songs of Period 1990s, while those with the source domain performance are prevalent in pop songs of Period 2000s.

\section{LIFE IS A JOURNEY}

In total, 54 metaphors of life with the source domain journey were found, falling into 36 and 18 metaphors identified in pop songs of Period 1990s and Period 2000s respectively. A PURPOSEFUL ACTIVITY IS A JOURNEY is the most frequently identified metaphor within the journey domain in pop songs of both time periods:

- Teach them well and let them lead the way (Whitney Houston, "Greatest Love Of AlI", 1895);

- Don't look back/Keep your head held high (Madonna, "This Used To Be My Playground", 1992).

Another frequent metaphor of life is PEOPLE ARE TRAVELLERS. Interestingly, this metaphor was only characteristic of Period 1990s:

- So what do we do with our lives?/We leave only a mark (Tina Turner, "We Don't Need Another Hero", 1985).

- Friends come and friends may go (Janet Jackson, "Alright", 1989).

The metaphor DIFFICULTIES ARE IMPEDIMENTS TO TRAVEL is very common to pop songs of Period 1990s, but occurs only once in pop songs of Period 2000s:

- Many things in this world bring you down /It's a wonder you can make it through the day (Whitney Houston, "Love Will Save The Day, 1987); 
- Friends tell me to hold on/Tough times don't last for long (Janet Jackson, "Come Back To Me", 1989);

- Who else am I gon' lean on? When times get rough (Mariah Carey, "We Belong Together", 2005).

In general, pop songs of Period 2000s reveal more metaphors related to change and motion as compared to pop songs of Period 1990s. This fact suggests that the woman of Period 2000s is more flexible and adaptive to changes than the woman of Period 1990s; she is able to initiate changes if they are needed. The metaphor CHANGE IS MOTION clearly illustrates this inference:

- So hold your head up girl and you'll go far (Lady Gaga, "Born This Way", 2011);

- I went from zero to my own hero (Katy Perry, "Roar", 2013).

Nevertheless, while demonstrating adaptability to changes, the woman also seeks guidance and support from her loved one, which is best manifested by the metaphor COUSELORS ARE GUIDES, indentified in pop songs of Period 2000s:

- But you'll still be my star (Rihanna, "Umbrella", 2007);

- Can you hold my hands and be my guide? (Beyoncé, "Sweet Dreams", 2008).

This aspect presupposes the complexity of the feminine world since the contemporary woman, while portraying herself as independent, at the core is the one who requires assitance and guidance in her life.

\section{LIFE IS A GAME}

The concept of life is also structured through the source domain game. Three kinds of metaphors of the source domain 'game' were identified in both time periods: LIFE IS A GAME, LIFE IS A GAMBLING GAME and LIFE IS A SPORTING GAME.

The perception of life as a game holds in both Period 1990s and Period 2000s: 
Julija VAITONYTĖ, Julija KOROSTENSKIENE்

- I'm the one who beat you at your own game (Aretha Franklin, "Who's Zoomin' Who", 1985);

- It doesn't matter if you win or lose/It's how you play the game so get into the groove (Madonna, "Causing a Commotion", 1987);

- Nobody likes being played (Beyoncé and Shakira, "Beautiful Liar", 2009).

The metaphors LIFE IS A GAMBLING GAME and LIFE IS A SPORTING GAME as structured by the metaphorical linguistic examples below, are more common to pop songs of Period 1990s:

- Lay all my cards out tonight/Just call on me baby (Whitney Houston, "I'm Your Baby Tonight", 1990);

- Give me one moment in time/When I'm racing with destiny (Whitney Houston, "One Moment In Time", 1997).

A relevant aspect is that references to life are often made when the concept of love is addressed. In a sense, the two concepts, life and love, become intertwined in pop songs of Period 1990s and Period 2000s. Assuming that love and emotional bonding are the fundaments of life, the fact that the two concepts are closely related is not surprising. On this view, the above metaphorical linguistic expressions drawn to illustrate the LIFE IS A GAMBLING GAME and LIFE IS A SPORTING GAME metaphors can also be regarded as references to the concept of love.

In this way, since sports are highly competitive and require physical and mental effort, whereas gambling involves a great deal of risk, structuring life in terms of the source domain game presupposes that in pop songs of Period 2000s life and, to a certain extent, love are conceived as competitive and risky.

\section{LIFE IS A DRAMATIC PERFORMANCE}

The group of conceptual metaphors of life with the source domain performance has the lowest number of occurrences relative to metaphors of life with the other two domains. In total, there were 10 metaphors of the LIFE IS $A$ DRAMATIC PERFORMANCE identified in pop songs of both time periods. 
Since LIFE IS A DRAMATIC PERFORMANCE is not a conventional conceptual metaphor it is the most revealing and can provide interesting insights into the feminine world construed in pop songs of the relevant periods. The conceptual metaphor LIFE IS A DRAMATIC PERFORMANCE was indentified twice in pop songs of Period 1990s: it appears in Madonna's song with a very suggestive title, "Take a Bow", which itself can be regarded as a reference to a notion that life is perceived in terms of a performance or show.

- You deserve an award for the role that you played (role that you played) (Madonna, "Take a Bow", 1995);

- All the world is a stage (world is a stage)/And everyone has their part (has their part) (Madonna, "Take a Bow", 1995).

In Period 2000s, Rihanna's song with the same title, "Take a Bow", contains several metaphors referring to performance:

- Curtain's finally closing/That was quite a show (Rihanna, "Take a Bow", 2008);

- But it's over now/Go on and take a bow (Rihanna, "Take a Bow", 2008).

The fact that these two pop songs come from different time periods yet have the same title is symbolic in a sense that they both employ theatrical terms, i.e., nouns a role, stage, curtains and applause to evoke the image of a woman who is at the epicentre of her lover's untruthful behaviour. The lines of Madonna's "Take a Bow": The show is over, say good-bye, suggest the end of a romantic relationship since the female characther in Madonna's song has been implicitly deceited, whereas in Rihanna's "Take a Bow" there is an explicit reference to the man being unfaithful. In both pop songs, show stands for the lover's deceitful behaviour following even broader assumption that, like actors and performers, men put on their masks to disguise their real intentions. Consequently, a female character becomes a victim who does not know she is being deceited, which, in turn, exposes her as a submissive and vulnerable woman.

Nevertheless, the metaphor LIFE IS A DRAMATIC PERFORMANCE can be viewed in a completely different perspective, which is a feature of pop songs of Period 2000s. Following the metaphorical correspondences that life is a dramatic 
Julija VAITONYTĖ, Julija KOROSTENSKIENE்

performance and people are actors or performers, it has been noted that in Britney Spears's "Circus" and Lady Gaga's "Applause" the focus shifts from the man to the woman since it is not the man, but the female character who becomes the leading actor as the metaphorical linguistic examples below illustrate:

- Well baby I'm a put-on-a-show kinda girl/Don't like the backseat, gotta be first (oh, oh) (Britney Spears, "Circus", 2008);

- There's only two types of people in the world/The ones that entertain, and the ones that observe (Britney Spears, "Circus", 2008);

- I live for the applause, applause, applause (Lady Gaga, "Applause", 2013).

These instances are a clear indication that the woman overtly seeks to be the leader and to subvert the general rule that the man is the one who takes up the leader's position. The woman wants to set the rules of her own to be observed by the man.

\section{Conceptual metaphors of time}

The concept of time is present in both time periods. In total, 21 conceptual metaphors of time were found, falling into 12 and 9 metaphors identified in pop songs of Period 1990s and Period 2000s respectively. Time is structured by two different source domains: movement and material entity. The conceptual metaphors with the source domain of movement include TIME IS A LANDSCAPE WE MOVE THROUGH and TIME IS A MOVING OBJECT, whereas the conceptual metaphors with the source domain of 'material entity' are TIME IS A RESOURCE and TIME IS MONEY.

\section{TIME IS MOVEMENT}

In pop songs of Period 1990s, time is mainly structured in terms of movement since metaphors the TIME IS A LANDSCAPE WE MOVE THROUGH and the TIME 
IS A MOVING OBJECT were most frequently identified in pop songs of this time period. Respectively, time is perceived as either staying still or moving.

The metaphorical linguistic expressions below structure the metaphor TIME IS A LANDSCAPE WE MOVE THROUGH:

- Soon we two are standing still in time (Madonna, "Crazy For You", 1985);

- We'll be making love the whole night through (Whitney Houston, "Saving All My Love For You", 1985).

In rendering time through landscape, emphasis is placed on the lovers in that when the lovers are still, there is no motion through time, and when they make love, time advances.

In the TIME IS A MOVING OBJECT metaphor, the concept of time is personified and thus made more dynamic:

- I prayed that the days would last/They went so fast (Madonna, "La Isla Bonita", 1986);

- Live and learn/Well the years they flew (Madonna, "This Used To Be My Playground", 1992).

Time is seen as the agent, which moves, and people are perceived as motionless since it is the days that go and years that flow. To sum up, in pop songs of Period 1990s, the conceptual metaphors TIME IS A LANDSCAPE WE MOVE THROUGH and the TIME IS A MOVING OBJECT indicate that time is seen from two different perspectives, as motionless and as moving.

In pop songs of Period 2000s, time is also highly associated with movement and, thus, structured by the conceptual metaphor TIME IS A MOVING OBJECT. The two following metaphorical linguistic expressions drawn to demonstrate the TIME IS A MOVING OBJECT metaphor in pop songs of Period 2000s are from Madonna's songs:

- Time goes by so slowly (Madonna, "Hung Up", 2005);

- Time is waiting (Madonna, "4 Minutes", 2008).

It is worth mentioning that in general, in Madonna's songs from both in Period 1990s and Period 2000s, the concept of time appears very often. 
Julija VAITONYTE், Julija KOROSTENSKIENE்

\section{TIME IS A MATERIAL ENTITY}

In pop songs of Period 2000s, time is conceived as both a moving object and as a material entity, which clearly shows that time is regarded as material, manifest as a resource or money. The TIME IS A RESOURCE metaphor is structured by the following metaphorical linguistic expressions:

- We really shouldn't waste no time (Rihanna, "Break It Off", 2007);

- Why you wasting your time? (Mariah Carey, "Obsessed", 2009).

The TIME IS MONEY conceptual metaphor is illustrated below:

- A few stolen moments is all that we share (Whitney Houston, "Saving All My Love For You", 1985);

- It's not worth our time (Beyoncé and Shakira, "Beautiful Liar", 2007). The perception of time in pop songs of two time periods does not differ substantially. While in Period 1990s time is mainly conceived through motion, in Period 2000s time is understood both as moving and material. The aspect that in pop songs of Period 2000s time is structured by two different domains (movement and material entity) provides two inferences. On the one hand, it can be assumed that nowadays the hectic pace of life has made time a value; on the other hand, conceiving time as a material entity presupposes that today's world is mainly centered on material things.

\section{Conclusions}

In pop songs of Period 1990s and Period 2000s, love is mainly conceived as a health condition and as a force and is expressed through more positive domains in Period 1990s, and more negative domains in Period 2000s. Usually love is structured as an interaction of two opposing poles, for instance, the LOVE IS BEING OFF THE GROUND metaphor may be realised as experiencing levitation when in love, and as crashing on the concrete, when heartbroken.

Metaphors of life show that the woman perceives life as a purposeful activity. The LIFE IS MOVEMENT metaphor reveals that a woman regarding life as a constant change is flexible. The LIFE IS A GAMBLING GAME and the LIFE IS 
A SPORTING GAME metaphors demonstrate that the woman conceives life as both competitive and risky. The LIFE IS A DRAMATIC PERFORMANCE metaphor, mostly identified in songs of Period 2000s, suggests that life is regarded as a dramatic performance, in which everyone has a certain role. Importantly, the woman seeks to take up the leading role, which undermines the notion that women, contrary to men, are not so prone to assume leadership.

Metaphors of time show that the concept of time is highly associated with movement since the TIME IS A LANDSCAPE WE MOVE THROUGH and the TIME IS A MOVING OBJECT metaphors are common to songs of both periods. In addition, in both periods time is perceived as material, and, in a sense, as a commodity, which presupposes that a woman not just lives in time, but uses up time as structured by the TIME IS A RESOURCE and the TIME IS MONEY metaphors.

As regards the feminine world as constructed through pop songs, the present analysis reveals that, while many songs contain references to pain caused by the breakup with the loved one or the unfaithfulness of the lover, the female protagonist is not portrayed as a weak creature. Rather, she is depicted as a warrior, in a sense, a heroine, who is not afraid of suffering, and at times unconsciously craves to suffer so that to demonstrate her great endurance. The contemporary woman living in today's hectic world is adaptive to changes, she is confident and determined. Metaphor analysis has also revealed that the woman exhibits and essentially values such qualities as strength, self-dependence, and fierceness.

Regarding the differences of the feminine "mind set" in the songs of the two periods, two conclusions can be made. First, the woman, as depicted in songs of Period 2000s, has become stronger and fiercer than the woman from songs of Period 1990s. The woman of the present times has a more aggressive attitude towards love: she prefers roughness in the relationships with her loved one. Second, the woman of Period 2000s has developed a more pragmatic attitude to life. Thus she sees life in terms of a dramatic performance: people are actors, who put on their masks to disguise their real intentions. 
Julija VAITONYTĖ, Julija KOROSTENSKIENE்

\section{References}

Charteris-Black, J. (2008) Metaphor as Models of Political Leadership. Available from:

https://www.dur.ac.uk/resources/mlac/research/metaphors_as_models/ Charteris2.pdf. [Accessed: $20^{\text {th }}$ January 2015].

Cameron, D. (2001) Working with Spoken Discourse. London: SAGE Publications Ltd.

Cserép, A. (2014) Conceptual Metaphor Theory: in defense or on the fence? Argumentum, 10, pp. 261-288.

Dhooge, B. W. (2010) Towards a new convergence between Anglo-American and Russian literary linguistics: "Mind style" and "kartina mira". Journal of literary semantics, 39 (2), pp. 143-165.

Fauconnier, G. (2003) Cognitive Linguistics. In NADEL, L. (ed.). Encyclopedia of Cognitive Science. London: Macmillan.

Gibbs, R. (2011) Metaphoric imagery as embodied cognition. Journal of Mental Imagery, 35, pp. 42-48.

Grady, J. (2005) Primary metaphors as inputs to conceptual integration. Journal of Pragmatics, 37, pp. 1595-1614.

Jørgensen, M. and Phillips, L. J. (2002) Discourse Analysis as Theory and Method. London: SAGE Publications Ltd.

Kövecses, Z. (2010) Metaphor: A Practical Introduction. New York: Oxford University Press.

Lakoff, G. and Johnson, M. (1980) Metaphors We Live By. Chicago: The University of Chicago Press.

Machin, D. (2010) Analysing Popular Music: image, sound, text. London: SAGE Publications Ltd.

Pragglejaz Group. (2007) MIP: A Method For Identifying Metaphorically Used Words in Discourse. Metaphor And Symbol, 22 (1), pp. 1-39.

Skinner, B. F. (1957) Verbal Behavior. New York: Appleton-Century-Crofts.

Steen, G. (2011) The contemporary theory of metaphor - now new and improved! Review of cognitive linguistics, 9 (1), pp. 26-64. 


\section{Computer software}

P.A.N. Poetry Analyzer. Available at: http://pan.sourceforge.net/ [Accessed November 2014].

\section{Julija Vaitonytè}

Vilniaus universitetas, Lietuva; julija.vaitonyte@gmail.com

\section{Julija Korostenskienè}

Vilniaus universitetas, Lietuva; julija.korostenskiene@uki.vu.It

\section{MOTERS IVAIZDIS ŠIUOLAIKINĖSE AMERIKIEČIU POP DAINOSE: LYGINAMOJI ANALIZÉ}

Santrauka. Jau daugiau nei dešimtmeti pažymima, jog metaforu analizè yra galinga priemonè, norint atskleisti žmogiškają patirti, užkoduotą ivairiose kalbos plotmèse. Šiame tyrime analizuojamas moters pasaulèvaizdis, atspindètas populiariausiu JAV dainininkiu pop dainose iš dvieju skirtingu dešimtmečiu - nuo 1985 m. iki 1995 m. ir nuo 2005 m. iki 2015 m., iškèlus hipotezę, jog net ir toje pačioje kultūroje tam tikros socialinès grupès pasaulio suvokimas per labai trumpa laika gali kisti, o pop dainos yra geriausias to pokyčio atspindys. Tyrimas grindžiamas konceptualiosios metaforos teorija, taip pat naudojama Pragglejaz grupès sukurta metodika konceptualiosoms metaforoms nustatyti ir P.A.N. poezijos analizavimo kompiuterinè programa tam, kad būtu atlikta kokybinè konceptualiuju metaforu analizè ir atkurtas dainose atspindimas moters pasaulèvaizdis. Tyrimo išvados remiasi iš 522 konceptualiuju metaforu išskirtu konceptu analize, kurie yra meilè, gyvenimas ir laikas. Abiejuose dešimtmečiuose vaizduojama šiuolaikinè moteris yra stipri, užsispyrusi ir nepriklausoma. Ankstesniame dešimtmetyje meilès konceptas vertinamas labiau teigiamai. Vèlesniame dešimtmetyje - meilès konceptui būdingas dinamiškumas, o moteris gyvenima suvokia kaip rizikinga - kuriame tenka konkuruoti. Nepaisant to, moteris yra pajègi prisitaikyti ir užimti lyderès pozicija meilès santykiuose. Be to, kaip parodè tyrimas, moteris vaizduojama vèlèsnio dešimtmečio dainose, yra agresyvesnè meileje bei apskritai daug pragmatiškiau žiūri i gyvenimą.

Pagrindinès sąvokos: konceptualioji metafora, moters pasaulèvaizdis, pop dainos, metaforu identifikavimo tvarka, tikslinè sritis. 